\title{
Correlation of udder shape, size and udder size of Bushuev breed of cows with milk yield
}

\author{
B.J. Nosirov ${ }^{1, *}, M . M$. Safarov, M. Gaipov ${ }^{2}, S . S$. Askarkhodjayeva $^{2}, U$. Soatov $^{1}$ and KH.T. \\ Javkarashev \\ ${ }^{1}$ Tashkent State Agrarian University, Universitetskaya str., 2, 100140, Tashkent, Uzbekistan \\ ${ }^{2}$ Tashkent branch of Samarkand Veterinary Medicine Institute, Temur str., Tashkent, Uzbekistan
}

\begin{abstract}
This article examines the relationship between the shape, size and size of the udder and udder of Bushuev cows on different categories of farms and their milk yield. It was determined that the milk yield of cows belonging to the form of bowl-shaped udder in all farms was higher from $720.9 \mathrm{~kg}$ to $641.8 \mathrm{~kg}$ than their peers belonging to the form of round udder. In comparison, the udder of cows with a cup-shaped udder was $3.3 \mathrm{~cm}$ to $2.2 \mathrm{~cm}$ wider, the udder length was $9.1 \mathrm{~cm}$ to $7.8 \mathrm{~cm}$ longer, and the udder circumference was 6.3 to $8.7 \mathrm{~cm}$ bigger, the udder depth was $1.6 \mathrm{~cm}$ to 2.7 $\mathrm{cm}$ longer, and the nipple diameter was higher $0.06 \mathrm{~cm}$ to $0.35 \mathrm{~cm}$, than the udder of cow belonging to a round udder. It was found that the daily milk yield in bowl-shaped udder cows was $29.3 \%$ to $25.4 \%$ higher than in their round udder-like counterparts.
\end{abstract}

\section{Introduction}

Dairy products are one of the most popular products in the world, and people consume a lot of dairy products throughout their lives. Due to the growing demand for dairy products, increasing the milk yield of cows has become an important task [1-2]. For this reason, different breeds of cows have been created around the world, and it has been observed that the milk yield of newly created breeds was higher than that of local breeds. In Uzbekistan, different breeds of cows have been created, including Bushuev, and this breed differs from other breeds by its highest quality; it is not affected by blood parasitic diseases, heat resistance, high fat content in milk and adaptability to local conditions. In the selection of cows on the farms and in scientific work, the selection is carried out only on the basis of productivity and exterior indicators [4-6]. But in practice, the work of choosing the udder of cows according to their Morpho-functional characteristics is almost not carried out. Therefore, the study of the shape, size of the udder of cows, the connection of its dimensions with milk yield determines the relevance of the topic.

It is known that the udder is one of the main organs in cows, which undergoes a complex physiological process and produces milk. Therefore, it is advisable for zoo engineers to evaluate cows based on the shape of the udder and the shape of the udder when evaluating the exterior [2-3]. The shape of the udder and nipples play an important role in the evaluation of the exterior. Scientists suggested that the milk yield of cows

${ }^{*}$ Corresponding author: soatov1978@mail.ru 
depends on a number of factors, namely the type of feed and feeding rate, storage conditions, breed, the activity of many endocrine glands $[2,4,5]$. When studying and evaluating the udder of cows, the following should be considered:1) the relationship between the shape and size of the udder and productivity, 2) the amount of milk and milking rate of each pacifier, 3) Anatomical and physiological properties of the udder. Scientists believe that different milk production from each udder of the udder during manual milking can lead to damage to the mucous layer canal of the cow udder and the milk tank of the cow. The front part of the cow's udder provides $40 \%$ of the total milk and the back part $60 \%$ [3, 6-10]. In Uzbekistan, the structure of the udder of cows and its characteristics have not been studied well, therefore, this research was intended 1) to study correlation between udder shape, and milk yield, 2) to determine amount of milk in the front and back parts of cow's udder, 3) to research udder size of different cow breeds, 4) to determine the suitability of cows for machine milking [2, 5-9].

\section{Materials and methods}

The research was carried out on the first Bushuev cows at the "Chinnur Durdona" farm in Kashkadarya region and at the "Turon Ravnaq Baraka" and "Mehri Daryo" breeding farms in the Syrdarya province of Uzbekistan.

For the experiment, three groups were formulated, such as $1^{\text {st }}$ control group in "Chinnur Durdona" farm, $2^{\text {nd }}$ experimental group in "Turon Ravnaq Baraka" farm, and $3^{\text {rd }}$ experimental group in "Mehri-daryo" farm; each group got 10 cows for the experimental purposes. Milk yield was monitored on a monthly basis to determine the amount of milk obtained. The fat content of milk was determined by the Herbert method. The suitability of cows for machine milking was determined according to a method developed during the milking period at 2 months [11-14]. The udder size and dimensions of cows are illustrated

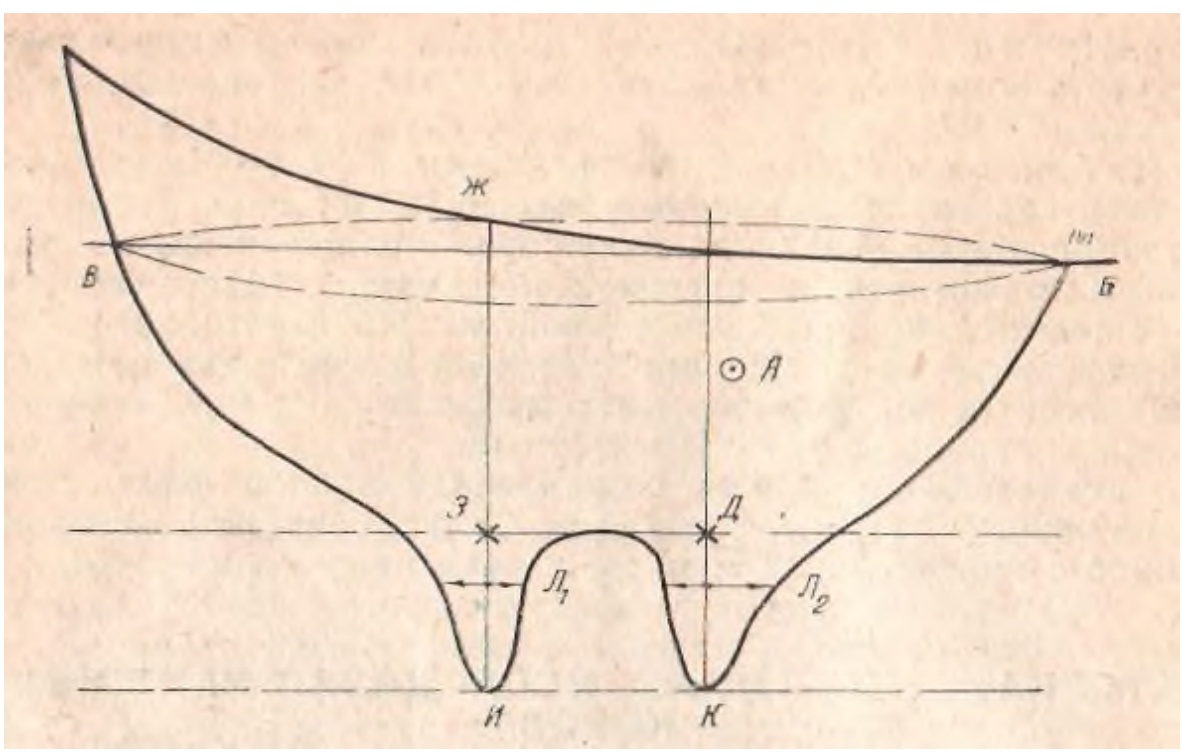

Fig. 1. Size of cow udder

in Figures 1 and 2 below.

"ВБ"-Circle of udder. The basis of the udder on the Cross is made from the previous part. "BM" -Length of udder. From the beginning of the front part of the udder to the back of 
the udder. "А" - Width of udder. "ВД"-Depth of front udder. From the abdomen to the base of the nipple. “ДКЗИ"-Length of front and back teat. “ЖЗ” -Length of the back part of the udder. " $\Omega_{1} Л_{2}$ "-Diameter of front and back teat [16-17]
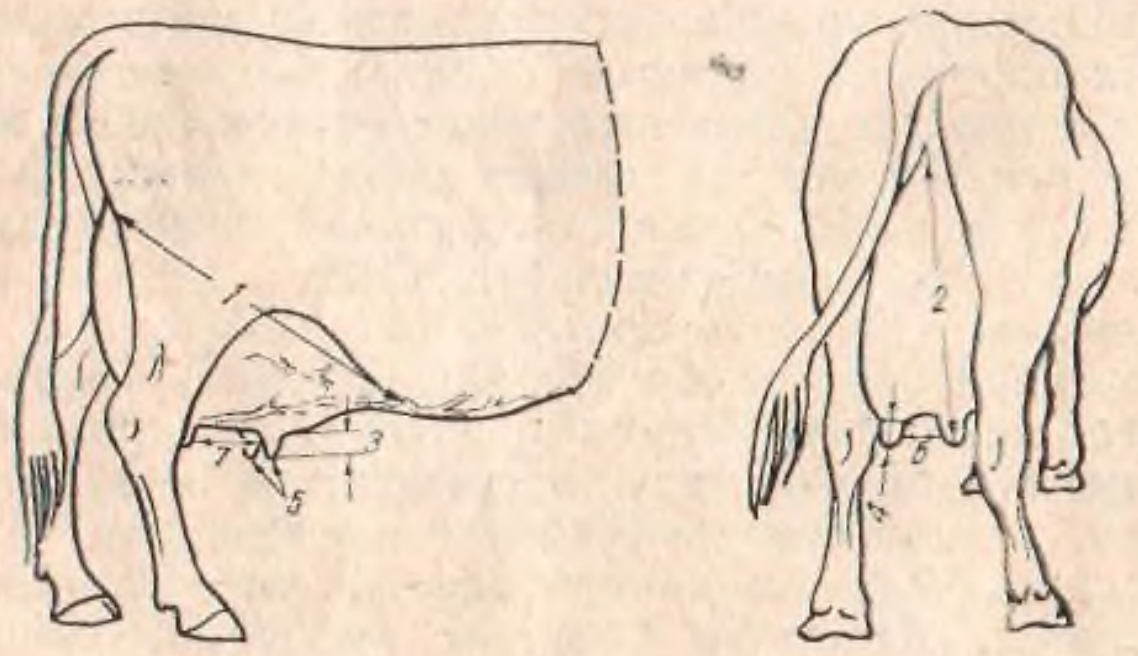

Fig. 2. Dimensions of cows` udder

1)-circle of the udder (from the beginning of the previous section to the exit of the udder of the back). 2) the depth of the udder. From the border of the udder window to the base of the back teat. 3) teat length, 4) teat circle, 5) range of front teats, 6) back teats range, 7) range of front and back teats. The obtained data were processed biometrically using the method of E.K. Merkureva [5].

\section{Results and discussion}

Milk yield of cows is considered one of the most basic selection signs and is an important character in cattle breeding. The milk yield of cows of Bushuev breed in farms of different categories was given in Table 1 .

Table 1. Milk yield of cows under observation, $\mathrm{kg} \mathrm{X} \pm \mathrm{Sx}$

\begin{tabular}{|c|c|c|c|}
\hline \multirow{2}{*}{ Indicators } & \multicolumn{3}{|c|}{ Groups } \\
\cline { 2 - 4 } & $\mathbf{I}(\mathbf{n}=\mathbf{1 0})$ & II $(\mathbf{n}=\mathbf{1 0})$ & III $(\mathbf{n}=\mathbf{1 0})$ \\
\hline Milk yield, kg & $2902.2 \pm 103.4$ & $3029 \pm 109.8$ & $3205 \pm 111.2$ \\
\hline $\begin{array}{c}\text { Fat amount in milk, } \\
\%\end{array}$ & $4.2 \pm 0.010$ & $4.1 \pm 0.02$ & $4.0 \pm 0.01$ \\
\hline Milk fat, kg & $120.6 \pm 0.93$ & $123.9 \pm 1.80$ & $129.7 \pm 1.03$ \\
\hline
\end{tabular}

According to this table, the milk yield of cows raised on a breeding farm was higher than that of peer cows raised on a commercial farm. The average milk yield of cows in group III was 3,205 kg, which was $303 \mathrm{~kg}$ (10.4\%) higher than in group I and $176 \mathrm{~kg}$ $(5.8 \%)$ higher than in group II. However, the fat content of milk was $0.2 \%$ lower than that of group I peers and $0.1 \%$ lower than that of group II peers. Milk fat was higher at 9.1 and 
$6.0 \mathrm{~kg}$, respectively. According to the results of several researches, the shape of the udder of a cow was related to its milk yield. According to Mustafayev A.M. [13,14], in Sirdarya region, $51.2 \%$ of the cows of Bushuev breed had the form of round udder, $37.6 \%$ had the form of cup and $11.2 \%$ had "goat udder". In this research, the shape and size of cows' udder were studied, and the pertinent results were given in Table 2.

Table 2. Udder and teat shape of cows in the experiment

\begin{tabular}{|c|c|c|c|c|c|c|c|c|}
\hline \multirow{4}{*}{$\begin{array}{c}\text { Shape of } \\
\text { udder and } \\
\text { teat }\end{array}$} & \multirow{4}{*}{$\stackrel{\mathscr{B}}{5}$} & \multirow{4}{*}{ 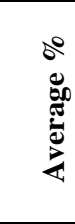 } & \multicolumn{6}{|c|}{ Groups } \\
\hline & & & \multirow{2}{*}{\multicolumn{2}{|c|}{$\begin{array}{c}\text { I }(\mathbf{n}=10) \\
\text { "Chinnur } \\
\text { durdona" } \\
\text { commodity farm }\end{array}$}} & \multirow{2}{*}{\multicolumn{2}{|c|}{$\begin{array}{c}\text { II }(\mathrm{n}=10) \\
\text { "Turon ravnak } \\
\text { baraka" breeding } \\
\text { farm }\end{array}$}} & \multirow{2}{*}{\multicolumn{2}{|c|}{$\begin{array}{c}\text { III }(\mathrm{n}=10) \\
\text { "Mehri daryo" } \\
\text { breeding farm }\end{array}$}} \\
\hline & & & & & & & & \\
\hline & & & Number & $\%$ & Number & $\%$ & Number & $\%$ \\
\hline $\begin{array}{c}\text { Udder: } \\
\text { Bowl-shape }\end{array}$ & 14 & 46.7 & 4 & 40.0 & 5 & 50.0 & 5 & 50.0 \\
\hline $\begin{array}{c}\text { Round-shaped } \\
\text { udder }\end{array}$ & 15 & 50.0 & 5 & 50.0 & 5 & 50.0 & 5 & 50.0 \\
\hline "Goat udder" & 1 & 3.3 & 1 & 10.0 & - & - & - & - \\
\hline $\begin{array}{c}\text { Teat: } \\
\text { Cylindric }\end{array}$ & 14 & 46.7 & 4 & 40.0 & 5 & 50.0 & 5 & 50.0 \\
\hline Hexagonal & 9 & 30.0 & 3 & 40.0 & 3 & 40.0 & 3 & 40.0 \\
\hline Conical & 7 & 23.3 & 3 & 20.0 & 2 & 10.0 & 2 & 10.0 \\
\hline
\end{tabular}

The second table shows that on average in all farms there were 14 cows $(46.7 \%)$ in the form of bowl-shaped udder, 15 cows in the form of round udder $(50.0 \%)$ and one cow had "goat udder" (3.3\%). There were no cows in the pedigree farms that belonged to the "goat udder" form. The analyzing of the teat shape showed that the number of cows was 14 heads (46.7\%); 9 cows $(30.0 \%)$ had hexagonal shaped-teats, whereas 7 cows $(23.3 \%)$ had conical-shaped teat. The shape of the udder is the dimensions of the udder that were roughly measured by the eye. The choice of cows depending on the size, shape and large size of the udder, which is the main element. Therefore, the measurements of cows udder and teat were taken, and the results were given in table 3 given below.

Table 3. Udder dimensions of cows in the experiment

\begin{tabular}{|c|c|c|c|}
\hline \multirow{2}{*}{ Dimensions } & \multicolumn{3}{|c|}{ Groups } \\
\cline { 2 - 4 } & I (n=10) & II (n=10) & III (n=10) \\
\cline { 2 - 4 } & $\begin{array}{c}\text { "Chinnur } \\
\text { durdona" } \\
\text { commodity farm }\end{array}$ & $\begin{array}{c}\text { "Turon ravnak } \\
\text { baraka" breeding } \\
\text { farm }\end{array}$ & $\begin{array}{c}\text { "Mehri daryo" } \\
\text { breeding farm }\end{array}$ \\
\hline Width & $23.9 \pm 0.54$ & $24.4 \pm 0.57$ & $26.2 \pm 0.67$ \\
\hline Length & $29.3 \pm 0.73$ & $30.1 \pm 0.61$ & $32.1 \pm 0.94$ \\
\hline Circle & $83.4 \pm 1.77$ & $86.9 \pm 1.69$ & $96.0 \pm 2.17$ \\
\hline Front par depth & $21.3 \pm 0.59$ & $21.0 \pm 0.57$ & $24.2 \pm 0.61$ \\
\hline Back part depth & $23.5 \pm 0.53$ & $24.4 \pm 0.59$ & $26.7 \pm 0.74$ \\
\hline Front teat length & $533 \pm 0.19$ & $5.7 \pm 0.18$ & $6.2 \pm 0.24$ \\
\hline Back teat length & $4.6 \pm 0.21$ & $4.9 \pm 0.19$ & $5.2 \pm 0.23$ \\
\hline Front teat diameter & $2.16 \pm 0.82$ & $2.21 \pm 0.79$ & $2.39 \pm 0.87$ \\
\hline Back teat diameter & $2.11 \pm 0.79$ & $2.13 \pm 0.81$ & $2.27 \pm 0.91$ \\
\hline Distance from ground to & $59.5 \pm 1.23$ & $59.1 \pm 1.26$ & $58.1 \pm 1.27$ \\
\hline udder & & &
\end{tabular}


According to the data in the table 3, there was a difference between the groups in terms of udder and udder sizes. In group III cows, the width of the udder was $1.8 \mathrm{~cm}(6.9 \%)$ compared to group II peers and $2.3 \mathrm{~cm}(8.8 \%)$ compared to group I. The reliability level of the difference between the groups was $\mathrm{R}>0.95$. The udder length in Group III cows were also higher than their peers in the other group, accordingly it was $32.1 \mathrm{~cm}$ in group III, followed by $2.0 \mathrm{~cm}(6.3 \%)$ longer compared to group II, and it was $2.8 \mathrm{~cm}(8.4 \%)$ longer in comparison with group I. The reliability of the difference was $\mathrm{R}>0.95$. The circumference of the udder was $96.0 \mathrm{~cm}$ in group III, which was $9.1 \mathrm{~cm}(2.5 \%)$ higher than in group II, $12.6 \mathrm{~cm}(13.2 \%)$ higher than in group I. Their diameter indicated whether they were suitable for machine milking or not. The length of teat in cows of group III was average of $5.7 \mathrm{~cm}$, which was $0.5 \mathrm{~cm}(8.8 \%)$ longer than in group II and $0.8 \mathrm{~cm}(14.1 \%)$ longer than in group I. The coefficient of variation in the size of the udder was higher in all groups, especially in the length and diameter of the teats, accounted for 10.1-20.2\%. This research work showed that milk yield in udder shape would be different both in the normal farm and in the breeding farm, and the milk yield of cows belonging to the form of bowl-shape udder would be higher than that of cows belonging to the form of round udder and "goat udder" (Table 4).

Table 4. The correlation of the shape and size of the udder and milk yield of cows

\begin{tabular}{|c|c|c|c|c|c|c|c|c|c|c|c|c|c|c|}
\hline \multicolumn{15}{|c|}{ Groups } \\
\hline \multicolumn{5}{|c|}{ I } & \multicolumn{5}{|c|}{ II } & \multicolumn{5}{|c|}{ III } \\
\hline \multirow[t]{2}{*}{ 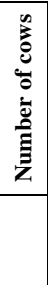 } & \multirow{2}{*}{ 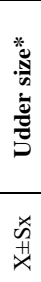 } & \multirow{2}{*}{ 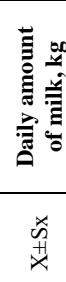 } & \multicolumn{2}{|c|}{ 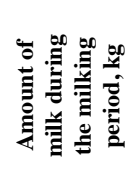 } & \multirow[t]{2}{*}{ 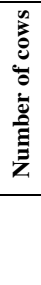 } & \multirow{2}{*}{ 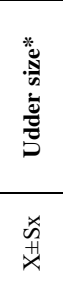 } & \multirow{2}{*}{ 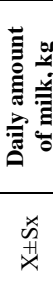 } & \multicolumn{2}{|c|}{ 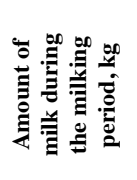 } & \multirow[t]{2}{*}{ 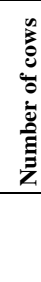 } & \multirow{2}{*}{ 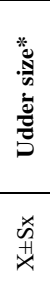 } & \multirow{2}{*}{ 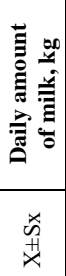 } & \multicolumn{2}{|c|}{ 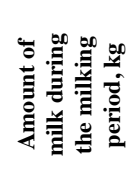 } \\
\hline & & & $\begin{array}{l}x \\
\ddot{x}\end{array}$ & $\begin{array}{l}* \\
* 0 \\
0^{\circ}\end{array}$ & & & & $\begin{array}{l}x \\
\ddot{x} \\
\ddot{x}\end{array}$ & $\begin{array}{l}* \\
* \\
\circ\end{array}$ & & & & 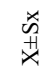 & $\begin{array}{l}* \\
2^{\circ}\end{array}$ \\
\hline \multicolumn{15}{|c|}{ Bowl-shape udder } \\
\hline + & 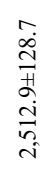 & 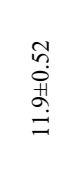 & 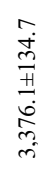 & 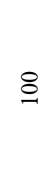 & in & 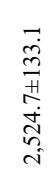 & 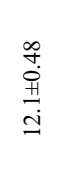 & 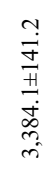 & 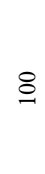 & n & 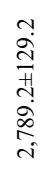 & 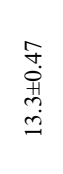 & 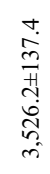 & 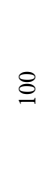 \\
\hline \multicolumn{15}{|c|}{ Round-shaped udder } \\
\hline in & 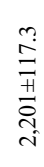 & $\begin{array}{l}\vec{\sim} \\
\stackrel{0}{ } \\
\text { N. }\end{array}$ & 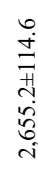 & $\stackrel{0}{\infty}$ & in & 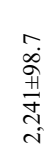 & $\begin{array}{l}m \\
\hat{0} \\
\text { H. } \\
\text { o. }\end{array}$ & 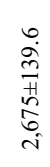 & $\stackrel{\circ}{\circ}$ & in & 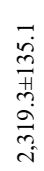 & $\begin{array}{l}\bar{m} \\
0 \\
0 \\
0 \\
0\end{array}$ & 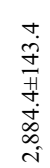 & $\stackrel{\infty}{\infty}$ \\
\hline \multicolumn{15}{|c|}{ "Goaty udder" } \\
\hline- & $\underset{f}{\mathfrak{f}}$ & $\stackrel{0}{\sim}$ & $\underset{\mathcal{N}}{\stackrel{N}{N}}$ & 官 & & ' & ' & & ' & ' & & ' & ' & \\
\hline 음 & 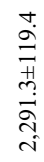 & & 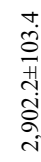 & & 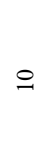 & 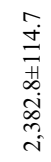 & $\begin{array}{l}F \\
\dot{0} \\
\dot{0} \\
\infty \\
0 \\
0\end{array}$ & 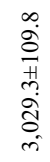 & & ㅇ & 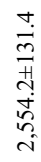 & 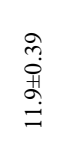 & 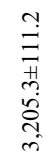 & \\
\hline
\end{tabular}


The research showed that in all farms, the milk yield of cows belonging to the bowlshaped udder was higher than that of their peers belonging to the round and "goat udder". For example, in cows belonging to the form of cup-shaped udder of the III group, the amount of milk was $3,526.2 \mathrm{~kg}$ and was $142.1 \mathrm{~kg}(4.2 \%)$ higher than in peers of the II Group and $150.1 \mathrm{~kg}(4.4 \%)$ higher than in the I Group. In Group III cows belonging to the same round udder shape, $2,884.4 \mathrm{~kg}$ was $209.4 \mathrm{~kg}(7.8 \%)$ higher than in Group II peers, and $229.2 \mathrm{~kg}(8.6 \%)$ higher than in Group III. In the II -and III-groups there were no cows belonging to the form of "goat udder". A similar indicator was observed in Group II to $709.1 \mathrm{~kg}(26.5 \%)$, in Group I to $720.9 \mathrm{~kg}(27.1 \%)$. And this, of course, was the fact that in the breeding farms carried out well selection and selection on the Morpho-functional characteristics of cows' udder. In cows belonging to the form of bowl-shaped udder in Group III, the round udder was $469.9 \mathrm{~kg}(20.2 \%)$ higher than their peers belonging to the form of udder. Furthermore, the udder size was $2789,2 \mathrm{~cm}^{2}$ in cows belonging to the form of the bowl-shaped udder of the III group, $264.5 \mathrm{~cm}^{2}(10.4 \%)$ compared to the II Group peers, $276.3(10.9 \%) \mathrm{cm}^{2}$ compared to the I Group, in cows of the III group the udder size was $2,319 \%$ (Table 4). Clearly, the size and shape of the udder have impact on the milk yield.

The data given in Table 5 below showed that in cows of Group III belonging to the form of the bowl-shaped udder, all udder sizes were higher than in the peer group. For example, cows of the III-group had $1.2 \mathrm{~cm}(4.6 \%)$ on the udder, $1 \mathrm{~cm}(2.8 \%)$ on the length of the udder, $10.3 \mathrm{~cm}(11.4 \%)$ on the udder, $2.8 \mathrm{~cm}(11.6 \%)$ on the depth of the udder, $0.6 \mathrm{~cm}$ $(11.4 \%)$ on the length of the udder and $0.30 \mathrm{~cm}(13.5 \%)$ on the diameter of the udder. Comparing udder sizes by udder shape, it can be seen that they were higher in cows with a bowl-shaped udder than those with a round udder shape. For example, the cows belonging to the form of the bowl-shaped udder of the III-group had higher udder diameter of $2.2 \mathrm{~cm}$ $(8,8 \%)$, udder length $(9,5 \%)$, udder depth of $2.7(11.2 \%)$, teats 'length of $0.25 \mathrm{~cm}(4.4 \%)$ and teats diameter of $0.35 \mathrm{~cm}(16.2 \%)$ than their peers in the form of round udder.

Table 5. Correlation of udder size with milk yield, $\mathrm{cm} \mathrm{X} \pm \mathrm{Sx}$

\begin{tabular}{|c|c|c|c|c|c|c|c|c|c|}
\hline \multirow[b]{2}{*}{ 兽 } & \multirow[b]{2}{*}{ 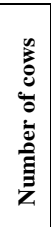 } & \multirow[b]{2}{*}{ 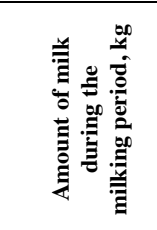 } & \multirow[b]{2}{*}{ 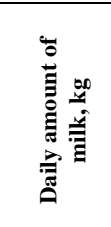 } & \multicolumn{6}{|c|}{ Dimensions of udder and teat } \\
\hline & & & & 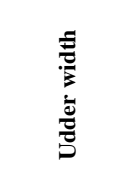 & 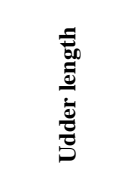 & 总 & 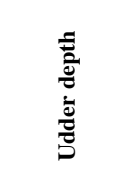 & 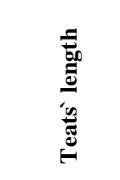 & 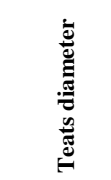 \\
\hline \multicolumn{10}{|c|}{ Bowl-shape udder } \\
\hline $\mathrm{I}$ & 4 & $3,376.1 \pm 134.7$ & $11.9 \pm 0.52$ & $25.9 \pm 0.52$ & $34.7 \pm 0.61$ & $89.4 \pm 1.79$ & $23.6 \pm 0.56$ & $5.2 \pm 0.19$ & $2.19 \pm 0.81$ \\
\hline II & 5 & $3,384.1 \pm 141.2$ & $12.1 \pm 0.48$ & $26.0 \pm 0.59$ & $35.0 \pm 0.77$ & $90 \pm 2.17$ & $24.0 \pm 0.63$ & $5.25 \pm 0.21$ & $2.21 \pm 0.79$ \\
\hline III & 5 & $3,526.2 \pm 137.4$ & $13.3 \pm 0.47$ & $27.2 \pm 0.49$ & $36.0 \pm 0.84$ & $100.4 \pm 1.84$ & $26.8 \pm 0.59$ & $5.85 \pm 0.27$ & $2.51 \pm 0.84$ \\
\hline \multicolumn{10}{|c|}{ Round-shaped udder } \\
\hline $\mathrm{I}$ & 5 & $2,655.2 \pm 114.6$ & $9.2 \pm 0.21$ & $22.6 \pm 0.49$ & $25.6 \pm 0.71$ & $83,1 \pm 1,63$ & $22.0 \pm 0.51$ & $5.1 \pm 0.21$ & $2.13 \pm 0.75$ \\
\hline II & 5 & $2,675.0 \pm 139.6$ & $9.4 \pm 0.33$ & $22.8 \pm 0.57$ & $25.2 \pm 0.69$ & $83,7 \pm 1,89$ & $22.4 \pm 0.57$ & $5.15 \pm 0.19$ & $2.14 \pm 0.84$ \\
\hline III & 5 & $2,884.4 \pm 143.4$ & $10.6 \pm 0.31$ & $25.0 \pm 0.55$ & $28.2 \pm 0.81$ & $91,7 \pm 1,78$ & $24.1 \pm 0.61$ & $5.6 \pm 0.24$ & $2.16 \pm 0.79$ \\
\hline \multicolumn{10}{|c|}{ "Goaty udder" } \\
\hline $\mathrm{I}$ & 1 & 2242 & 7.6 & 22.0 & 26.4 & 61.2 & 18.1 & 5.1 & 2.12 \\
\hline II & - & - & - & - & - & - & - & - & - \\
\hline III & - & - & - & - & - & - & - & - & - \\
\hline
\end{tabular}




\section{Conclusion}

In all farms, the milk yield of cows belonging to the bowl-shaped udder was higher than that of their peers belonging to the round and "goat udder". For example, in cows belonging to the form of cup-shaped udder of the III group, the amount of milk was $3,526.2 \mathrm{~kg}$ and was $142.1 \mathrm{~kg}(4.2 \%)$ higher than in peers of the II Group and $150.1 \mathrm{~kg}(4.4 \%)$ higher than in the I Group. In Group III cows belonging to the same round udder shape, 2,884.4 kg was $209.4 \mathrm{~kg}(7.8 \%)$ higher than in Group II peers, and $229.2 \mathrm{~kg}(8.6 \%)$ higher than in Group III. In the II -and III-groups there were no cows belonging to the form of "goat udder".

Moreover, the length of the udder from $3.3 \mathrm{~cm}(14.6 \%)$ to $2.2 \mathrm{~cm}(8.8 \%)$, the length of the udder from $9,1 \mathrm{~cm}(35.5 \%)$ to $7.8 \mathrm{~cm}(27.6 \%)$, the circumference of the udder from 6.3 $\mathrm{cm}(7.6 \%)$ to $8.7 \mathrm{~cm}(9.5 \%)$, udder dep $(0.25 \%)$ from $0.06 \mathrm{~cm}(2.8 \%)$ to $0.35 \mathrm{~cm}(16.2 \%)$, up to $0.25 \mathrm{~cm}(4.4 \%)$ the depth of the udder from $1.6 \mathrm{~cm}(7.2 \%)$ to $2.7 \mathrm{~cm}(11.2 \%)$, the length of the sliders from $0.1 \mathrm{~cm}(1.9 \%$ to $0.25 \mathrm{~cm}(4.4 \%)$, the teat diameter from $0.06 \mathrm{~cm}$ $(2.8 \%)$ to $0.35 \mathrm{~cm}(16.2 \%)$ were higher in cows in the form of bowl-shaped than their peers in the form of a round udder. Overall, it can be said that farms, specialized cows breeding, need to feed cows belong to the form of bowl-shaped udder towards meeting demands of people for milk production. Furthermore, these type cows would fit well to machine milking rather than cows with "goaty udder".

\section{References}

1. M. Gašparík, J. Ducháček, L. Stádník, V. Tančin, Scientia agriculturae bohemica 50(2), 4-16 (2019)

2. S. Soeharsono, S. Mulyati, S. Utama, W. Wurlina, P. Srianto, T. Restiadi, I. Mustofa, Veterinary world 13(3), 11 (2020)

3. F. Karakuş, N.M. Ilyas, Uluslararası Çevresel Eğilimler Dergisi 4(2), 15 (2020)

4. Z. Prpić, I. Vnučec M. Benić, M. Konjačić, N. Ugarković, B. Mioč, Journal of Central European Agriculture 21(2), 45-49 (2020)

5. A. Avizov, T. Akmalkhanov, U. Ballasov, Veterinary medicine 5, 1564-1572 (2008)

6. B. Baibolov, Uzbekistan Agriculture journal 6, 11 (2006)

7. M. D. Dedov, N. V. Savkin, Zootechnic 2, 618-625 (2004)

8. M. H. Dosmukhamedov, Zoo-veterinary 9, 7 (2008)

9. A. P. Lazarevic, A. A. Lazarevic, Husbandry 2, 23-29 (2005)

10. V. Lemenkov, V. Dobrianov, O. Sidorova, Dairy and meat cattle breeding 3, 6 (2003)

11. E. N. Martinova, V. A. Bichkova, E. V. Achkasova, Zootechnic 2, 1-14 (2001)

12. A. Mustafaev, Zoo-veterinary., 5 (2013)

13. A. Nurmatov, E. Umarov, B. Baibolov, D. Rakhmonov, Uzbekistan Agriculture journal 1, 56-59 (2008)

14. L. Kibalko, N. Tikachevo, N. Goncharova, Dairy and meat cattle breeding 5, 1218 (2010)

15. E. M. Kisyakova, E. V. Achkasova, Zootechnic 1, 89-93 (2009)

16. F. Sobirov, S. Dystkulov, M. Norboeva, Collection of the II International Scientific Conference, 10 (2008)

17. O. V. Pershina, Zootechnic 6, 12-15 (2011) 